\title{
IV. RENEWABLE ENERGY SOURCES AND BIOFUELS
}

\section{GENERALIZED APPROACH FOR FEASIBILITY STUDY OF HYBRID SYSTEMS WITH RENEWABLE ENERGY SOURCES}

\author{
Ivan Bachev, Boris Demirkov, Ludmil Stoyanov, Vladimir Lazarov, \\ Zahari Zarkov, Gilles Notton, Andrei Damian
}

\begin{abstract}
The purpose of this work is to assess the energies produced by a hybrid system composed of photovoltaic generators and wind turbines. This study aims to develop a method, which could facilitate the sizing of photovoltaic and wind generators in a given hybrid system. The proposed method could also help with the sizing of storage devices in the hybrid system, which provide energy for the consumer in moments when the primary renewable energy source is lacking or for sizing the energy exchange with the grid.
\end{abstract}

Key words: feasibility study, hybrid systems, photovoltaic and wind generator

\section{INTRODUCTION}

The depletion of the conventional energy sources and the fight with climate change has triggered an increase in the research and use of renewable energy sources worldwide [1]. The most used renewable energy sources (RES) are the energy of water, solar energy and the energy of the wind [2].

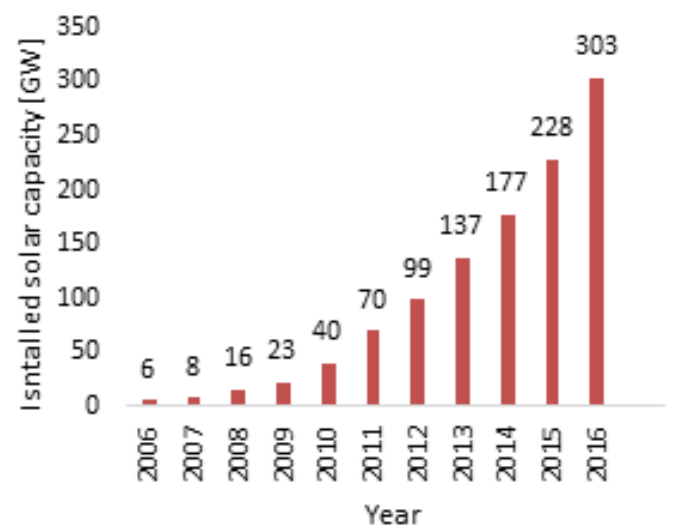

It should be noted that the use of water energy requires more complex structures like the presence of certain relief features at the installation site resulting in higher investments. On the other hand, we have observed an upward trend in the installed capacity of wind generators and photovoltaic generators - Fig. 1.

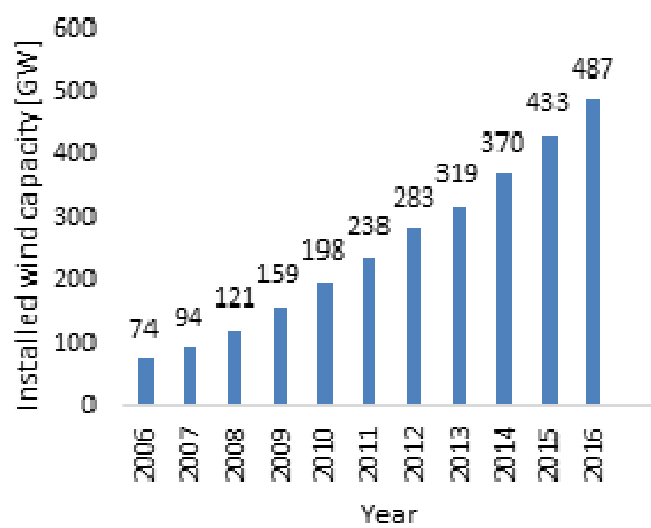

Fig. 1. Worldwide installed capacity of wind generators and photovoltaic generators.

A serious obstacle to the widespread use of solar or wind power generators is the stochastic nature of the primary source and the lack of guaranteed power. The problem, caused by the intermittent nature of the primary renewable energy sources and the non-guaranteed power supply for the consumers could be tackled through the combination of different sources of energy in a single hybrid system [3]. A renewable energy hybrid system is such an electrical system composed of more than one energy source and at least one renewable energy source [4]. The hybrid system could also contain storage devices like batteries, supercapacitors, hydropumping stations etc. This concept becomes more and more common by integration of RES in the buildings and the urban areas.

The sizing of generators in the hybrid system is essential because it can prevent financial losses and/or power outages. In the literature can be encountered many studies devoted to this problem [5], [6]. Typically, these surveys are targeted to a particular installation site or consider an already installed system.

The aim of this work is to propose a more generalized method of sizing and feasibility study of hybrid systems with renewable energy sources using as an input the variation of the primary resources on the installation site and the load for given time 
period. The proposed approach is applied to a hybrid system with photovoltaic (PV) and wind (WT) generators for different installation sites in Bulgaria, France and Romania.

\section{APPROACH DESCRIPTION}

The proposed approach uses data from the meteorological conditions on the installation site for a given time period and for the demands of the consumer during this period. On the basis of the meteorological conditions the output power of the photovoltaic and wind generators is calculated. For each calculation step the generated power is compared to the consumed one. This allows analysis of the necessity of storage presence and/or connection to the electrical grid, as well for assessment of the hybrid system performance.

The main advantage of the proposed approach lies in the use of per unit (p.u.) values instead of the SI units (International System of Units). Thus, the approach becomes universal and can be adapted to different installation sites, generators with various powers, loads with different power or type and different types of storage devices. The major advantage in using a per-unit system is the simplification of the calculations and the possibility to quickly check the correctness of the results [7]. Moreover results can be easily compared in the aim to determine the most appropriate configuration of the hybrid system.

\subsection{Primary potential estimation}

In the literature some methods, permitting to calculate the energy potential of a given site, using meteorological databases e.g. GIS or NASA [8], [9] can be encountered. From statistical point of view, it is necessary to use real measured data over a long period of time from the installation site of the hybrid system. In addition, data should be with small step, which helps take into account the fluctuations of the primary sources of renewable energy and take into account the different particularities of the production and consumption of energy [10], [11], [12]. Thus, the need to install a storage device or to provide a grid connection can be assessed. As an optimal compromise between the accuracy of the calculations and the volume of the data used, an incrementing step of one hour has been established. Such a step is also used in the proposed approach without imposing restrictions on a smaller or bigger calculation step.

The meteorological data necessary for the approach is:
- Global solar radiation for a horizontal plane $\left(G_{a}, \mathrm{Wh} / \mathrm{m}^{2}\right)$;

- Wind speed at $10 \mathrm{~m}$ height $\left(V_{10}, \mathrm{~m} / \mathrm{s}\right)$;

- Ambient air temperature $\left(T_{a},{ }^{\circ} \mathrm{C}\right)$.

To be used in the calculations of the energy production, the meteorological data should be transformed into "useful" data, corresponding to the conditions imposed on the electrical generators. The global solar radiation $G_{a}$ is measured on a horizontal plane, while most of the photovoltaic generators are inclined. In this study the conversion is realized using the method shown in [13]. The measured wind speed is converted for the average height of the wind turbine because of its height gradient [14]. The conversion uses the Justus formula [15]:

$$
V_{h}=V_{10}\left(\frac{h}{10}\right)^{\alpha},
$$

where $V_{h}$ is the wind speed on the hub height $h$ and $\alpha$ is the Hellmann Exponent, depending on the on the terrain type [16].

\subsection{Estimation of the PV generator output power}

The output power of the PV generator in p.u. $p_{P V}$ is determined by the expression:

$$
p_{P V}=\frac{P_{P V_{-} \text {out }}}{P_{P_{\text {_b base }}}},
$$

where $P_{P V_{-} \text {out }}$ is the actual output power of the generator and $P_{P V_{b} \text { base }}$ is the base power of the photovoltaic generator.

The base power corresponds to the installed peak power of the photovoltaic generator and is determined under standard test conditions (STC):

$$
P_{P V_{-} \text {base }}=\eta_{S T C} G_{S T C} A,
$$

where $\eta_{S T C}$ is the PV panels efficiency at STC, $G_{S T C}$ - global solar radiation at standard test conditions, usually equal to $1000 \mathrm{~W} / \mathrm{m}^{2}$, and $A-$ the $\mathrm{PV}$ installation area.

The actual output power is calculated by:

$$
P_{P V_{-} \text {out }}=\eta_{P V} G_{\beta} A,
$$

where $\eta_{P V}$ is the efficiency of the panel at real meteorological conditions and $G_{\beta}$ is the solar irradiation on the inclined panels' plane.

The substitution of (3) and (4) in (2) gives:

$$
p_{P V}=\frac{P_{P V_{-} \text {out }}}{P_{P_{\text {_b base }}}}=\frac{\eta_{P V} G_{\beta} A}{\eta_{S T C} G_{S T C} A}=\frac{\eta_{P V} G_{\beta}}{\eta_{S T C} G_{S T C}},
$$


In the expression (5) the power in p.u. is independent of the area of the photovoltaic installation. Thus the approach is applicable to different systems - with different installed power and composed by PV panels from different technologies. At identical meteorological conditions the approach allows the comparison of the performance of PV generators, composed by panels with different efficiency at STC, because the ratio $\eta_{P V} / \eta_{S T C}$ actually reflects the relative change of the efficiency depending on the operation conditions (cells temperature, solar irradiation). The power $p_{P V}$ in (5) does not depend on the PV installation area but varies according to the meteorological conditions, taken into account by the change of the solar radiation $G_{\beta}$ and of the efficiency $\eta_{P V}$.

The panels' efficiency at real meteorological conditions is determined with simplified Durisch's model. The original model of Durisch is expressed by [17]:

$\eta_{p v}=p\left[q \frac{G_{\beta}}{G_{\beta, r e f}}+\left(\frac{G_{\beta}}{G_{\beta, \text { ref }}}\right)^{m}\right] \times\left[1+r \frac{T_{\text {cell }}}{T_{\text {cellref }}}+s \frac{A M}{A M_{0}}+\left(\frac{A M}{A M_{0}}\right)^{u}\right]$,

where $G_{\beta, \text { ref }}=1000 \mathrm{~W} / \mathrm{m}^{2}$ is the solar irradiance at STC, $T_{\text {cell }}$ is the PV panels' temperature, $T_{\text {cell, ref }}=$ $25^{\circ} \mathrm{C}$ is the panels' temperature at STC, $A M$ is the air mass, with reference value $A M_{0}=1.5, p, q, m, r, s$ and $u$ are empirical parameters, determined for different PV modules.

The panels' temperature is determined as function of the ambient temperature and the solar radiation by the formula:

$$
T_{\text {cell }}=T_{a}+h G_{\beta},
$$

where $h$ is an empirical parameter depending on the PV technology.

Previous authors' studies show that the influence of the air mass in the model (6) could be neglected without sensible precision loss and with significant calculation reduction (thanks to the elimination of the air mass computation) [18]. The air mass neglect transforms equation (6) into:

$$
\eta_{p v}=p\left[q \frac{G_{\beta}}{G_{\beta, r e f}}+\left(\frac{G_{\beta}}{G_{\beta, r e f}}\right)^{m}\right] \times\left[1+r \frac{T_{\text {cell }}}{T_{\text {cell, ref }}}\right] .
$$

\subsection{Estimation of the wind generator output power}

There are numerous approaches of modelling the performance of a wind generator. One of these approaches uses the real power curve of the generator [19], [20], [21]. Another possibility is to use a power curve obtained by a mathematical model. The wind generator's power curve model presented by Pallablazzer [22] is one of the most commonly used [23], [24]. It is possible to use the wind power and the efficiency of the wind turbine and electrical generator. Exactly this variant is chosen for this study and is exposed bellow.

The output power of the wind generator in p.u. $p_{W T}$ is determined by:

$$
\left\{\begin{array}{cc}
p_{W T}=0 & V_{h} \leq V_{\text {cut-in }} \\
p_{W T}=\frac{P_{W T_{-} \text {out }}}{P_{W T_{-} \text {base }}} & V_{\text {cut-in }}<V_{h} \leq V_{\text {rated }} \\
p_{W T}=1 & V_{\text {rated }}<V_{h}<V_{\text {cut } \text { off }}
\end{array}\right.
$$

where $P_{W T_{-} \text {out }}$ is the wind generator output power in real units, $P_{W T_{-} \text {base }}$ is the base power for conversion in p.u., $V_{\text {cut-in }}$ is the cut-in wind speed of the wind turbine, $V_{\text {rated }}$ is the rated wind speed and $V_{\text {cut-off }}$ is the cut-off wind speed.

The base power, as for the PV generator, is equal to the rated power of the wind generator and can be expressed by the formula:

$$
P_{W T_{-} \text {base }}=P_{\text {rated }}=\frac{1}{2} \cdot \rho \cdot V_{\text {rated }}^{3} \cdot A_{s} \cdot C_{p r} \eta_{\text {genr }}
$$

where $P_{\text {rated }}$ is the rated power of the wind generator, $\rho=1.25 \mathrm{~kg} / \mathrm{m}^{3}$ is the air density, $A_{s}$ is the wind turbine swept area, $C_{p r}$ is the rated power coefficient (equivalent of the efficiency) of the wind turbine and $\eta_{\text {genr }}$ is the rated efficiency of the electrical generator, which takes into account the losses in the electrical generator and the power converters, if available.

The actual output power of the wind generator is expressed by:

$$
P_{W T_{-} \text {out }}=\frac{1}{2} \cdot \rho \cdot V_{h}^{3} \cdot A_{s} \cdot C_{p} \eta_{\text {gen }},
$$

where $C_{p}$ is the actual power coefficient of the wind turbine and $\eta_{g e n}$ is the actual efficiency of the electrical generator. 
The substitution of (10) and (11) in (9) gives:

$$
\left\{\begin{array}{cc}
p_{W T}=0 & V_{h} \leq V_{\text {cut }- \text { in }} \\
p_{W T}=\frac{P_{W T_{\text {_out }}}}{P_{W T_{-} \text {base }}}=\frac{\frac{1}{2} \cdot \rho \cdot V_{h}^{3} \cdot A_{s} \cdot C_{p} \eta_{\text {gen }}}{\frac{1}{2} \cdot \rho \cdot V_{\text {rated }}^{3} \cdot A_{s} \cdot C_{p r} \eta_{\text {genr }}}=\frac{V_{h}^{3} C_{p} \eta_{\text {gen }}}{V_{\text {rated }}^{3} C_{p r} \eta_{\text {genr }}} & V_{\text {cut-in }}<V_{h} \leq V_{\text {rated }} \\
p_{W T}=1 & V_{\text {rated }}<V_{h}<V_{\text {cut } \text { off }}
\end{array}\right.
$$

In equation (12) the output power in p.u. does not depend on the wind turbine swept area. In the common case the wind turbine power coefficient and the generator efficiency are function of the wind speed and the rated power. In this study it is considered that the power coefficient does not change and its value is 0.4 . The generator efficiency is also accepted for constant, equal to 0.9. Similar assumptions are common in the literature, like in [25]. According to these assumptions the output power in p.u. depends only on the ratio of the wind speeds:

$$
p_{W T}=\frac{V_{h}^{3}}{V_{\text {rated }}^{3}} \text { for } V_{c u t-i n}<V_{h} \leq V_{\text {rated }} .
$$

\subsection{Estimation of the consumed power}

The sizing of the hybrid system needs data for the consumers that will be powered. In the present study it is considered that the hybrid system control cannot influence the load. To determine the load power in p.u. $p_{\text {load }}$ is used the expression:

$$
p_{\text {load }}=\frac{P_{\text {load }}}{P_{\text {load_base }}}
$$

where $P_{\text {load }}$ is the actual consumed power and $P_{\text {load_base }}$ is the base power of the load.

The base power is the maximal power of the load during the studied period. It can be considered as the total installed power of all consumers with the assumption that they does not operate with power, greater than the rated one:

$$
P_{\text {load_base }}=\max \left(P_{\text {load }}\right)
$$

The actual load power as well as the load profiles are known in advance. For this purpose can be used real measurement or databases. In this study is used annual load profile with one hour step obtained from [26].

\subsection{Storage and grid connection}

The proposed approach can be used to estimate the need, the rated power and the capacity of the storage or the grid connection. In the calculations it is possible to consider different possibilities and types of storage devices. The assumption in the present study is for connection with ideal grid, which is also equivalent to a initially charged ideal storage with infinite power and capacity.

\subsection{The hybrid system in p.u.}

The load maximal power is used as a base power to determine the powers in the hybrid system. For the hybrid system sizing are variated the ratios of the installed generator and load powers. For this purpose are used the coefficients $k_{P V}$ and $k_{W T}$. Then for each computation step the energy balance is calculated. The difference between the generated and consumed power, if any, is exchanged with the electrical grid or with the storage. The energy balance is expressed by:

$$
k_{P V} p_{P V}+k_{W T} p_{W T}=p_{\text {load }} \pm\left\{\begin{array}{c}
p_{\text {grid }} \\
p_{\text {storage }}
\end{array}\right.
$$

where $p_{\text {grid }}$ and $p_{\text {storage }}$ are the power exchanged between the hybrid system and respectively the grid or the storage.

The coefficient $k_{P V}$ and $k_{W T}$ reflect the ratio of the respective rated generators' powers to the load installed power as follows:

$$
k_{P V}=\frac{P_{P V_{-} \text {base }}}{P_{\text {load_base }}} \text { and } k_{W T}=\frac{P_{W T_{-} \text {base }}}{P_{\text {load_base }}}
$$

The coefficients can be also expressed with the areas of the installed generators according to the considerations above:

$$
k_{P V}=\frac{A}{A_{\text {base }}} \text { and } k_{W T}=\frac{A_{s} V_{\text {rated }}}{A_{s_{-} \text {base }} V_{\text {rated_base }}}
$$

where $A_{\text {base }}$ is the area of a photovoltaic generator with rated power equal to the maximal load power and $A_{s_{-} \text {base }}$ is the swept area of a wind turbine with rated power (and rated wind speed $V_{\text {rated_base) }}$ equal to the load maximal power. 
It is important to note that there are no theoretical limitations of the ratios between the generators' and load power, i.e. the coefficients $k_{P V}$ and $k_{W T}$, which can be changed from 0 to values exceeding 1. Taking into account the lack of guaranteed power from renewable energy generators, the installed power of the generators may be higher than the installed power of the consumers. When the optimal values of the coefficients are determined for the given location, it is easy to determine the rated powers of the photovoltaic and wind generator by the actual installed load power and to realize the hybrid system.

\section{APPROACH APPLICATION}

The proposed approach is applied to different installation sites and different consumers, typical for the test sites. Hourly data for the variation of the meteorological conditions and the load profile during one year are used. Three installations sites are considered (one for each ISERBATURB project participant) - Kaliakra in Bulgaria, Ajaccio in France and Bucharest in Romania. They are characterized by different primary energy potential and different load profile. On the basis of the meteorological data, the output power of the photovoltaic and wind generator is calculated and then compared to the load. Thus the need of storage and/or grid connection is determined. In this paper results for three possible configurations are shown:

- Configuration 1 - the photovoltaic and the wind generator rated powers are equal to the installed load power $k_{P V}=k_{W T}=1$;

- Configuration 2 - the photovoltaic generator has two times less installed power than the wind generator and the load $k_{P V}=0.5, k_{W T}=1$;

- Configuration 3 - the wind generator has two times less installed power than the photovoltaic generator and the load $k_{P V}=1, k_{W T}=0.5$;

Some results are presented below.

Fig. 2 - Fig. 4 present results for the three installation sites for configuration 1. In the above graph, in each figure the variation of the generated (with light) and the consumed (with dark) power, and the below - the difference between them (for more information the zero axis is bolded) are depicted. On the figures below, when the difference is positive the generated power is greater than the consumed one and vice versa - the negative difference means that the consumed power is greater than the generated one. The difference in the powers is exchanged with the grid or the storage device.
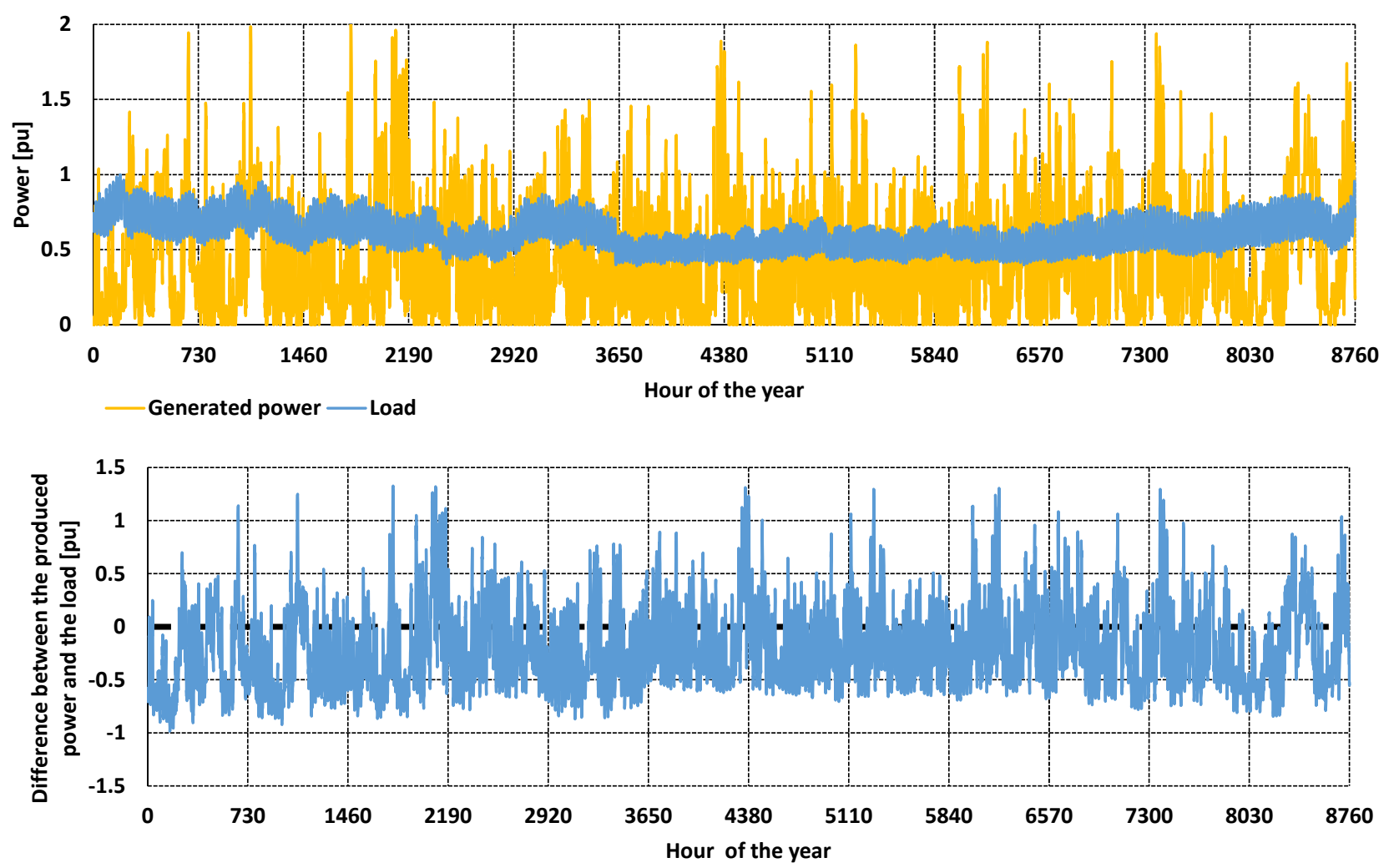

Fig. 2. Variation of the generated and consumed power (above) and their difference (below) for Kaliakra with configuration 1 

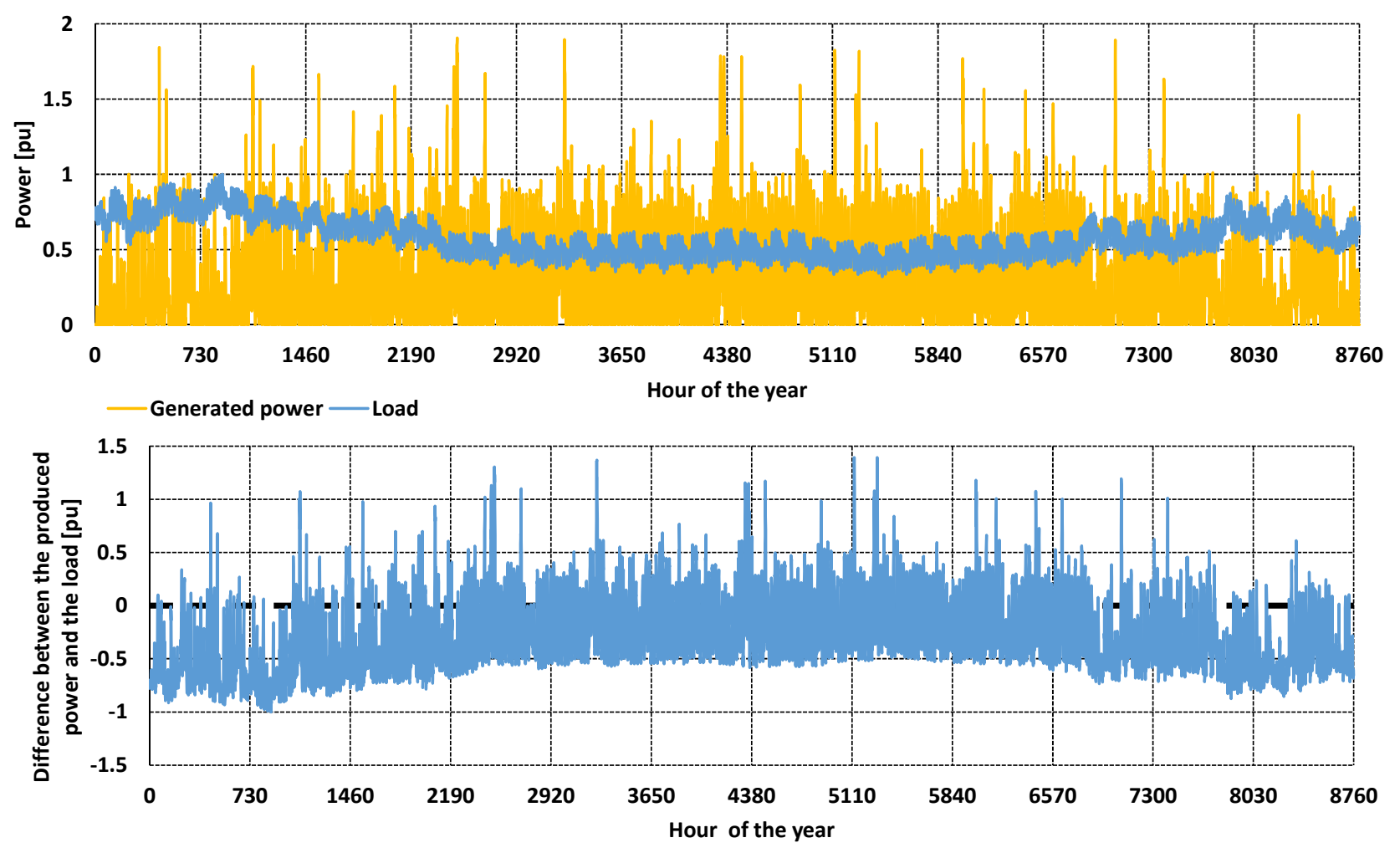

Fig. 3. Variation of the generated and consumed power (above) and their difference (below) for Ajaccio with configuration 1
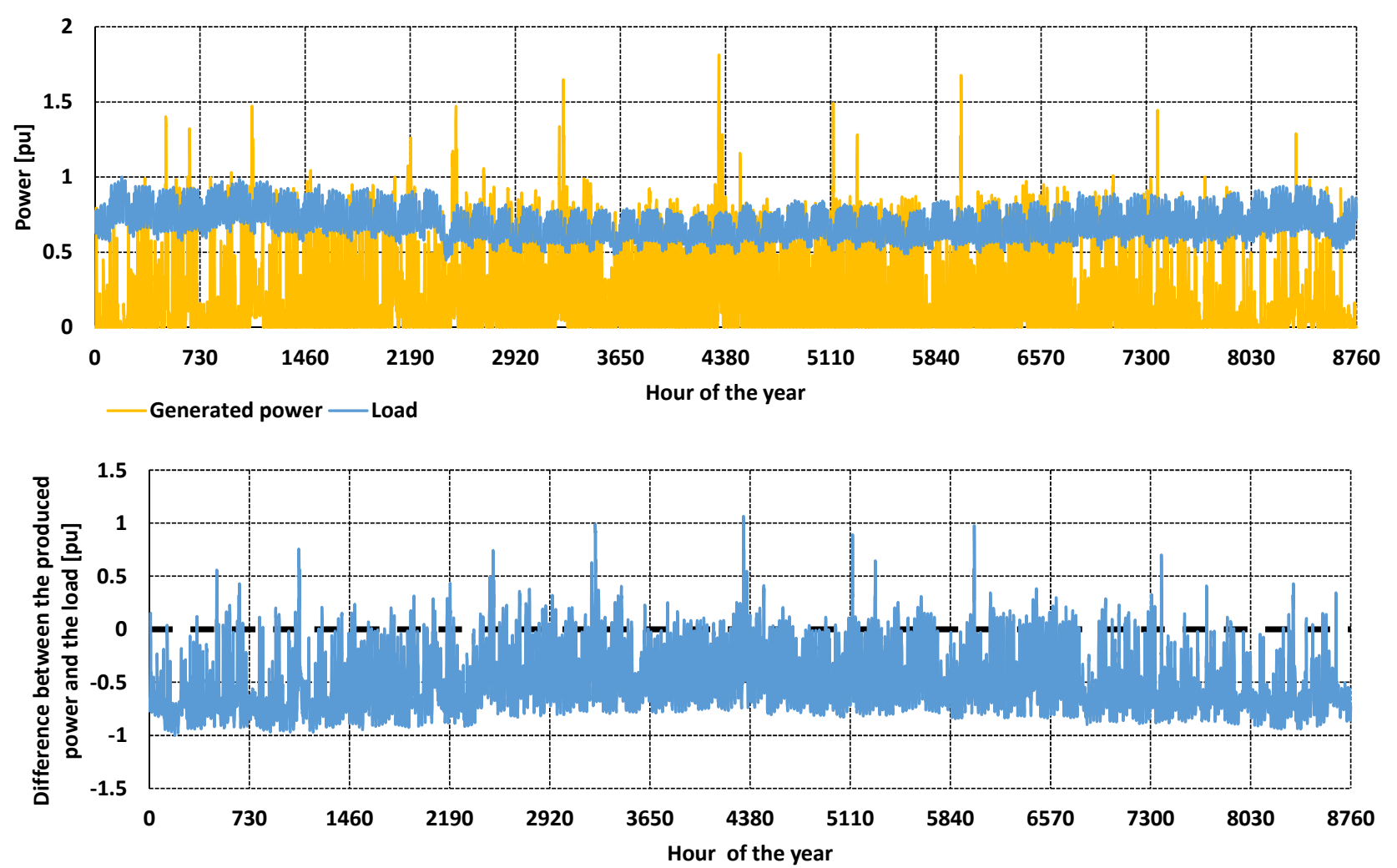

Fig. 4. Variation of the generated and consumed power (above) and their difference (below) for Bucharest with configuration 1 
For more clarity on Fig. 5 the variation of the power for one week period in June for hybrid system with configuration 1 in Ajaccio is presented.
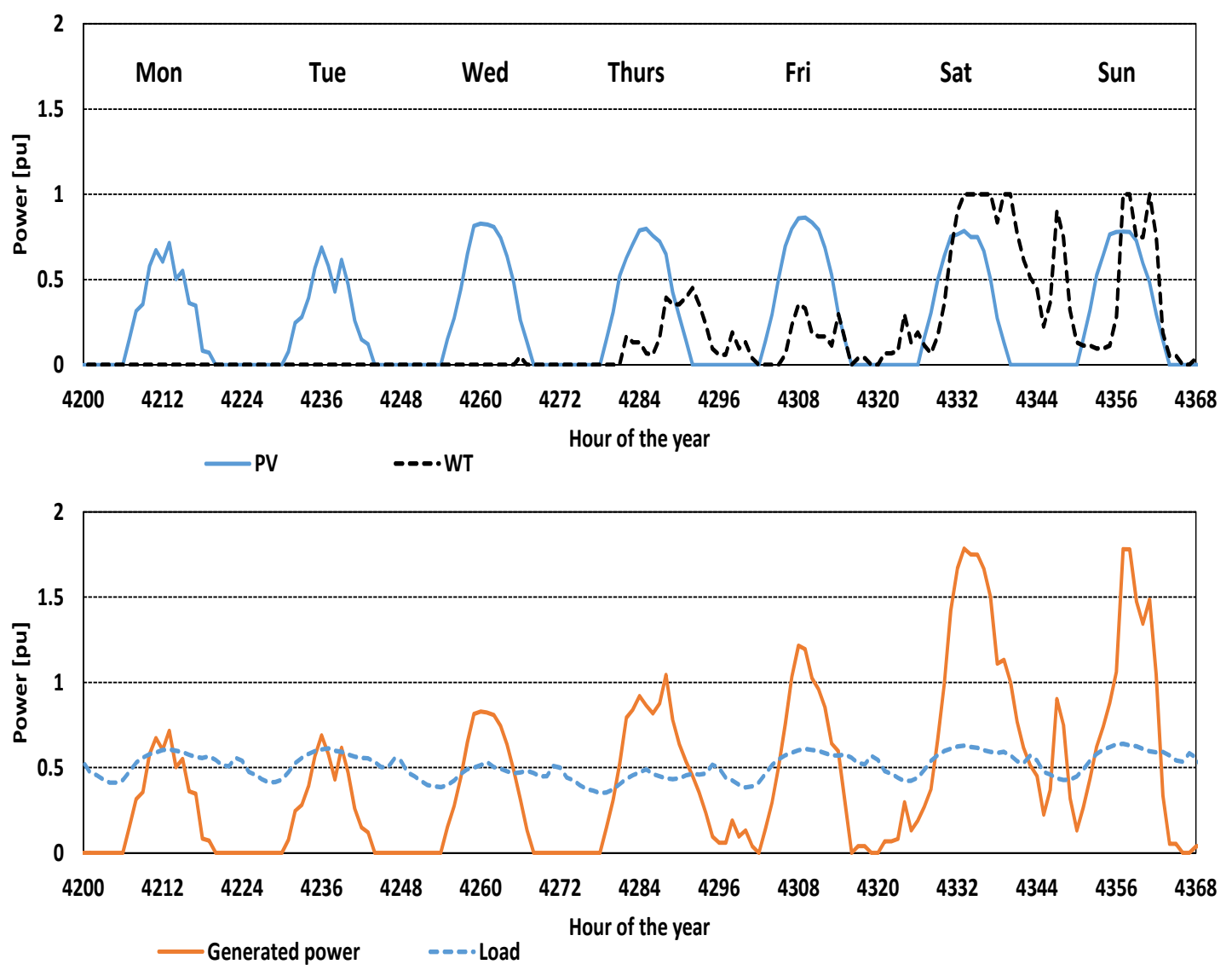

Fig. 5. Variation of the output power of the photovoltaic and wind generator (above) and the total generated and consumed power (below) for one week in June

The above graph on the Fig. 5 shows that during the first 3 days of the week only the solar power is available. In the second half of the week the wind power appears with an increase in the weekend especially in the afternoon and the night. The sum of the two generated powers can supply the load only for few hours in Monday and Tuesday (the graph below). For the next three days during the day we observe a positive difference while in the night the system has a lack of energy so a storage or grid connection is needed. When high wind speeds appear during the weekend, storage is used almost only to accumulate the energy excess.
As the considered week is in June the load power varies around 0.5 p.u.

Table 1 presents a summary of the results for the different sites and configurations. The maximal difference means the maximal absolute value of the difference between the generated power and the load. The absolute value of this difference gives information about the needed storage power or the exchanged power with the grid.

The annual energy balance gives information about how balanced is the hybrid system from point of view of the equilibrium between generated and consumed energy. The expression for the annual energy balance $E_{\text {year }}$ is:

$$
E_{\text {year }}=\sum_{i=1}^{n}\left\{\begin{array}{c}
p_{\text {grid_i }} \\
p_{\text {storage } i} i
\end{array}\right\} . \Delta t=\sum_{i=1}^{n}\left(k_{P V} p_{P V_{-} i}+k_{W T} p_{W T_{-} i}-p_{\text {load_ } i}\right) . \Delta t
$$

where $\Delta t$ is the computation step ( 1 hour in this case), $\mathrm{n}$ is the number of computation steps (8760). 
This information allows the estimation of the need of storage and assists its choice. The negative values show that during the year there were more hours with energy lack, while the positives one - more energy excess. The negative values of $E_{\text {year }}$ mean that the hybrid system needs grid connection or more generator power to ensure the power supply of the load.

Table 1: Results summary for the different sites and configurations

\begin{tabular}{|c|c|c|l|}
\hline Site & Configuration & Maximal difference, $[\mathrm{pu}]$ & $E_{\text {year }},[\mathrm{pu} . \mathrm{h}]$ \\
\hline \multirow{3}{*}{ Kaliakra } & 1 & 1,33 & $-1956,5$ \\
\cline { 2 - 4 } & 2 & 0,985 & $-2755,5$ \\
\cline { 2 - 4 } & 3 & 0,985 & $-2899,4$ \\
\hline \multirow{3}{*}{ Ajaccio } & 1 & 1,39 & $-2686,2$ \\
\cline { 2 - 4 } & 2 & 1 & $-3626,9$ \\
\cline { 2 - 4 } Bucharest & 3 & 1 & $-2974,5$ \\
\cline { 2 - 4 } & 1 & 1,066 & $-4442,2$ \\
\cline { 2 - 4 } & 2 & 1 & $-5190,0$ \\
\hline \multirow{3}{*}{ Tyyy } & 3 & 1 & $-4554,9$ \\
\hline
\end{tabular}

The results analysis allows the conclusion that for all considered configurations an energy lack on annual basis exists. The results show that Kaliakra and Ajaccio are more favorable installation sites for the hybrid system, because the lack of energy (the negative annual energy balance) is smaller. Among the three considered configurations only the first one is interesting but with requirement for storage or grid connection presence. For all three sites the hybrid system needs greater generators because of the poor primary potential.

For example for configuration 1 in Bucharest, due to the very small wind potential, the wind generator does not contribute significantly to the energy balance, despite its rated power is equal to the load's maximal power. The increase of the wind generator installed power (configuration 3 ) in this case will not improve the situation, because the wind potential is very low and the wind generator will not work most of the time. The solar potential of Ajaccio and Bucharest is considerably greater than the wind one and the decrease of the installed power of the PV generator leads to significant increase of the lack of energy.

Kaliakra possesses comparable solar and wind potential and the difference between the second and the third configuration is small i.e. the solar and the wind energy almost equally contribute to the total energy balance.

\section{CONCLUSIONS}

This study presents a generalized approach for feasibility study and sizing of hybrid systems with renewable energy sources. The approach is universal, because it uses per unit and it is applicable to different installation sites, generators, consumers and load profiles. On the basis of meteorological data for the installation site and the load profile the variation of the generated and consumed power is calculated. In this paper the used data is with one hour step for a one-year period but it is possible the use of other step or period of time. The approach application allows the estimation of the need of storage and/or electrical grid connection. The obtained results in addition to the sizing of the hybrid system components authorize to forecast the schedule of the energy, exchanged with the electrical grid. Such information is of great importance to the operators of the distribution grid, where the examined hybrid systems would be connected. The approach is illustrated by studies for three sites in the ISERBATURB project participants - Kaliakra (Bulgaria), Ajaccio (France) and Bucharest (Romania). The results show that the considered configurations are not optimal and require storage with high capacity. A capacity reduction, but at the expense of increased power, can be realized by increase of the installed powers of the generators. The ratio of the installed powers of the generators can be optimized through an iterative procedure according to different criteria: minimal storage capacity, minimal storage power, minimal quantity of non-satisfied energy etc.

\section{Acknowledgement}

The authors extend thanks to the AUF (Agence universitaire de la francophonie) for the exchange support within the framework of project ISERBATUB and the DUNK01/3 project (of Bulgarian National Research Fund) for the scientific infrastructure support. 


\section{REFERENCES}

1. REN21, Renewables 2016 Global Status Report. Renewable Energy Policy Network for 21 Century, 2016.

2. International Renewable Energy Agency (IRENA), Data and Statistics, available online: http://resourceirena.irena.org/gateway/dashboard/?to pic $=4 \&$ subTopic $=19$ accessed 27.10.2017.

3. Sawle, Y., Gupta, S.C. \& Bohre, A.K. (2017) Review of hybrid renewable energy systems with comparative analysis of off-grid hybrid system, Renewable and Sustainable Energy Reviews, In press, corrected proof, Available online 30 June 2017.

4. Lazarov, V. D., Notton, G., Zarkov, Z. \& Bochev, I., Hybrid power systems with renewable energy sources - types, structures, trends for research and development. Proceedings of International Conference ELMA2005, Sofia, Bulgaria, pp. 515-520, 2005.

5. Upadhyay, S. \& Sharma, M.P. A review on configurations, control and sizing methodologies of hybrid energy systems, Renewable and Sustainable Energy Reviews, Volume 38, 2014, pp 47-63.

6. Belmili, H., Haddadi, M., Bacha, S., Almi, M.F. \& Bendib B. Sizing stand-alone photovoltaicwind hybrid system: Techno-economic analysis and optimization, Renewable and Sustainable Energy Reviews, Volume 30, 2014, pp. 821-832.

7. Sen, P. C., Principles of electric machines and power electronics - Third edition. New York: John Wiley \& Sons, 2013, ISBN 978-1-118-07887-7.

8. Ermolenko, B. V., Ermolenko, G.V., Fetisova, Y.A. \& Proskuryakova, L.N., Wind and solar PV technical potentials: Measurement methodology and assessments for Russia, In Energy, Volume 137, 2017, pp. 1001-1012.

9. Hermann, S., Miketa, A. \& Fichaux N., Estimating the Renewable Energy Potential in Africa, IRENA-KTH working paper, International Renewable Energy Agency, Abu Dhabi, 2014.

10. Ireland, G., Hughes, A. \& Merven, B., A techno economic renewable hybrid technology mini-grid simulation and costing model for off-grid rural electrification planning in Sub-Saharan Africa, 2017 International Conference on the Domestic Use of Energy (DUE), Cape Town, 2017, pp. 179-186.

11. Li, R., Wu, B., Li, X., Zhou, F. \& Li, Y., Design of wind-solar and pumped-storage hybrid power supply system, 2010 3rd International Conference on Computer Science and Information Technology, Chengdu, 2010, pp. 402-405.

12. Creayla, C.M.C. Garcia, F.C.C. \& Macabebe, E.Q.B., Next Day Power Forecast Model
Using Smart Hybrid Energy Monitoring System and Meteorological Data, Procedia Computer Science, Volume 105, 2017, pp. 256-263.

13. Notton, G., Poggi, P. \& Cristofari, C., Predicting hourly solar irradiations on inclined surfaces based on the horizontal measurements: Performances of the association of well-known mathematical models. Energy Conversion and Management vol. 47, Issue 13-14, 2006, pp. 1816-1829.

14. Hladik, J., Énergétique éolienne: applications pratiques, chauffage éolien, production d'électricité, pompage. Masson, 1984.

15. Justus, C.G., Winds and system performances. Philadelphia, Franklin Institute Press, 1978.

16. Kaltschmitt, M., Streicher W. \& Wiese A., Renewable Energy: Technology, Economics and Environment. Springer-Verlag Berlin Heidelberg, 2007.

17. Durisch, W., Bitnar, B., Mayor, J.C., Kiess, H., Lam, K.H. \& Close, J., Efficiency model for photovoltaic modules and demonstration of its application to energy yield estimation. Solar Energy Materials and Solar cells, 91, 2007, pp.79-84.

18. Zarkov, Z., Stoyanov, L., Milenov, V., Voynova, H. \& Lazarov, V., Modeling of PV Generators from Different technologies" - Case Study, 2016 IEEE International Power Electronics and Motion Control Conference (PEMC'2016), 2016, pp. 412-417.

19. Ai, B., Yang, H., Shen, H. \& Liao, X., Computer-aided design of $\mathrm{PV} /$ wind hybrid system. Renewable Energy, vol. 28, 2003, pp. 1491-1512.

20. Koutroulis, E., Kolokotsa, D., Potirakis, A. \& Kalaitzakis, K., Methodology for optimal sizing of stand-alone photovoltaic/wind-generator systems using genetic algorithms. Solar Energy, vol. 80, pp2006, 1072-1088.

21. Bernal-Agustín, J.L., Dufo-López, R. \& Rivas-Ascaso, D.M., Design of isolated hybrid systems minimizing costs and pollutant emissions. Renewable Energy, vol. 31, 2006, pp. 2227-2244.

22. Pallabazzer, R., Evaluation of wind generator potentiality. Solar Energy, vol. 55, 1995, pp. 49-59.

23. Notton, G., Cristofari, C., Poggi, P. \& Musseli, M., Wind hybrid electrical supply system: behaviour simulation and sizing optimization. Wind Energy, vol. 4, 2001, pp. 43-59.

24. Prasad, A.R. \& Natarajan, E., Optimization of integrated photovoltaic-wind power generation systems with battery storage. Energy, vol. 31, 2006, pp. 1943-1954. 
25. Diaf, S., Haddadi, M. \& Belhamel, M., Analyse technico économique d'un système hybride (photovoltaïque/éolien) autonome pour le site d'Adrar. Revue des Energies Renouvelables, vol. 9, N 3, 2006, pp. 127-134.
26. European Network of Transmission System Operators for Electricity (ENTSO-E) - Power Statistics, https://www.entsoe.eu/data/statistics/Pages/default. aspx (Retrieved 10.06.2017)

\title{
ОБОБЩЕН ПОДХОД ЗА ОРАЗМЕРЯВАНЕ НА ХИБРИДНИ СИСТЕМИ С ВЪЗОБНОВЯЕМИ ИЗТОЧНИЦИ НА ЕНЕРГИЯ
}

\author{
Иван Бачев, Борис Демирков, Людмил Стоянов, Владимир Лазаров, \\ Захари Зарков, Жил Нотон, Андрей Дамиан
}

\begin{abstract}
Резюме: Целта на това изследване е да оцени произведените енергии от хибридна система, съставена от фотоволтаични и вятьрни генератори. За целта е разработен подход, улесняващ оразмеряването на инсталираните мощности на фотоволтаичен и вятърен генератор. Предложеният подход може да подпомогне избора на акумулиращо устройство, което да осигури захранване на товара при липса на достатьчно произведена енергия, или оценка на енергийния обмен с мрежата.
\end{abstract}

Ключови думи: хибридни системи, фотоволтаични и ветрогенератори

\section{MSc. Eng. Ivan Bachev, PhD student}

Technical university of Sofia

e-mail: iv.bachev@tu-sofia.bg

MSc. Eng. Boris Demirkov, PhD student

Technical university of Sofia

e-mail: demirkov@tu-sofia.bg

Assoc. Prof. Dr. Ludmil Stoyanov

Technical university of Sofia

e-mail: 1udiss@tu-sofia.bg

\section{Prof. Dr. Vladimir Lazarov}

Technical university of Sofia

e-mail: vl_lazarov@tu-sofia.bg

Assoc. Prof. Dr. Zahari Zarkov

Technical university of Sofia

e-mail: zzza@tu-sofia.bg

\section{Assoc. Prof. Dr. Gilles Notton}

University of Corsica

e-mail: gilles.notton@univ-corse.fr

Assoc. Prof. Dr. Andrei Damian

Technical University of Civil Engineering, Bucharest e-mail: adamian7@yahoo.com маг. инж. Иван Бачев, докторант

Технически университет - София

e-mail: iv.bachev@tu-sofia.bg

маг. инж. Борис Демирков, докторант

Технически университет - София

e-mail: demirkov@tu-sofia.bg

доц. д-р Людмил Стоянов

Технически университет - София

e-mail: 1udiss@tu-sofia.bg

проф. Д-р Владимир Лазаров

Технически университет - София

e-mail: vl_lazarov@tu-sofia.bg

доц. д-р Захари Зарков

Технически университет - София

e-mail: zzza@tu-sofia.bg

доц. д-р Жил Нотон

Университет на Корсика

e-mail: gilles.notton@univ-corse.fr

доц. д-р Андрей Дамиан

Технически университет по строителство, Букурещ e-mail: adamian7@yahoo.com 